\title{
Determination of Arsenic in Drinking Water Samples by Electrothermal Atomic Absorption Spectrometry after Preconcentration Using the Biomass of Aspergillus niger Loaded on Activated Charcoal
}

\author{
Mohsen Shahlaei ${ }^{1}$ and Alireza Pourhossein ${ }^{2}$ \\ ${ }^{1}$ Medical Biology Research Center, Kermanshah University of Medical Sciences, Kermanshah, Iran \\ ${ }^{2}$ Young Researchers Club, Kermanshah Branch, Islamic Azad University, Kermanshah, Iran \\ Correspondence should be addressed to Alireza Pourhossein; apourhossein@ymail.com
}

Received 28 May 2013; Revised 16 September 2013; Accepted 4 November 2013; Published 16 January 2014

Academic Editor: Hossain Md Anawar

Copyright (c) 2014 M. Shahlaei and A. Pourhossein. This is an open access article distributed under the Creative Commons Attribution License, which permits unrestricted use, distribution, and reproduction in any medium, provided the original work is properly cited.

\begin{abstract}
A simple, fast, and sensitive method for determination of total arsenic in drinking water sample by ETAAS after solid phase preconcentration has been developed. The dead biomass of $A$. niger loaded on activated charcoal has been applied as bioadsorbent for preconcentration step. The effects of parameters such as $\mathrm{pH}$, type and concentration of eluent, biosorption time, sample volume, and effect of interfering ions have also been studied. Under the optimum condition, the enrichment factor of 10 for the analyte has been obtained. The accuracy of the method has been investigated by the recovery of spiked standards and the recovery percents between 99 and 102\% have been achieved. Total amount of arsenic was determined by reducing As (V) to As (III) with potassium iodide (KI) and ascorbic acid in $\mathrm{HCl}$ solution. Under the optimum conditions, for $400 \mathrm{~mL}$ of drinking water samples, the detection limit $(3 \sigma)$ and linear range were achieved $1 \mathrm{ng} / \mathrm{mL}$ and $5-100 \mathrm{ng} / \mathrm{mL}$, respectively. The relative standard deviation for ten determinations of a spiked sample with concentration of $10 \mathrm{ng} / \mathrm{mL}$ As was $3.2 \%$.
\end{abstract}

\section{Introduction}

Arsenic is a toxic trace element widely distributed in nature. The malignant symptoms may appear even when trace arsenic is ingested. The toxicity mechanism of arsenic has been shown that it binds to enzymes, which are inhibited for functioning [1]. Arsenic is present in water, soils, rocks, and all living things (plants and animals); also, it is accumulative poison that affects all bodily systems [24]. Because of its high toxicity, it is of great importance to regularly monitor and recover arsenic from different samples such as natural waters. Recently, WHO prescribes a limit of $10 \mathrm{ng} / \mathrm{mL}$ for total As in drinking waters [5]. The analysis of such low levels demands highly sensitive techniques. Some analytical techniques have been used for trace determination of arsenic such as colorimetry $[6,7]$, atomic absorption spectrometry $[7,8]$, hydride generation system combined with atomic absorption spectrometry [9], inductively coupled plasma mass spectrometry $[10,11]$, and atomic fluorescence spectrometry [12]. Recently, electrothermal atomic absorption spectrometery has been extremely used as a powerful technique for determination of arsenic in various samples [13]. The results obtained by ETAAS show good sensitivity and low detection limits. But the sensitivity of analysis by ETAAS can decrease because of aging of graphite tube which is used as atomizer. Therefore in order to achieve accurate, sensitive and reliable results at ultratrace levels of As with ETAAS, preconcentration step is required prior to analyte determination. A number of procedures involving liquidliquid extraction [14], anodic stripping voltammetry [15], hydride generation atomic fluorescence spectrometry [16, 17], energy-dispersive X-ray fluorescence, and solid phase extraction [18] have been used for the determination of the low concentration levels of arsenic. Recently, solid phase extraction, using microbial biomass, has been studied as an alternative method for preconcentration of trace elements 
for determination of contaminants in waters. Biological microorganisms including fungi [19], yeast [20, 21], bacteria [22], and algae [23] have been shown to efficiently accumulate trace elements from aqueous solutions. Recently, several review articles $[24,25]$ are published that illustrate the latest developments in the biosorption of metals by microbial biomass for analyte preconcentration, matrix separation, and speciation analysis. Because of many binding sites on the cell wall of microorganisms they have good ability for adsorption of trace elements from solutions. The biomass of Aspergillus niger, the byproduct of citric acid fermentation, has also been used for preconcentration of some trace elements such as iron [26], lead and nickel [27], and chromium, copper, zinc, and cadmium [28]. The previous works have used $A$. niger loaded on silica gel and sepiolite for preconcentration of analytes [26-28]. Littera et al. applied biomass of $A$. niger for removal of arsenic from aqueous environments in native and modified forms [29]. The aim of this study is the use of $A$. niger, loaded on activated charcoal, as biosorbent, for preconcentration of As in water samples prior to determination with ETAAS. Some effective parameters such as $\mathrm{pH}$, sample volume, type and concentration of eluents, and effect of interfering ions, have been optimized. The method was applied successfully for preconcentration of arsenic prior determination with ETAAS.

\section{Experimental}

2.1. Preparation of Biosorbent. The A. niger strain used in this work was prepared from the Kimia Gharb Industrial Company, Kermanshah, Iran. The biomass was produced by transferring of spores to the fermentation medium according to our previous work [30]. The grown cells were then separated with filtration, rinsed several times with deionized water, and then oven-dried at $80^{\circ} \mathrm{C}$ for $24 \mathrm{~h}$. For the biosorption studies, the dried biomass was ground to powder in a disintegrator and sieved to a diameter of $0.05-$ $0.1 \mathrm{~mm}$. The biomass produced was separated by filtration and the resulting biomass was washed thoroughly for several times with distilled water. The biomass was treated with hydrochloric acid (1N), washed with distilled water to bring the $\mathrm{pH}$ of the biomass in neutral range, and dried in an oven at $105^{\circ} \mathrm{C}$ for $24 \mathrm{hr} .600 \mathrm{mg}$ of dry A. niger was mixed with $2.0 \mathrm{~g}$ of granular activated charcoal (meshes $4-12$ ). $5 \mathrm{~mL}$ of water was added to the mixture and thoroughly mixed. After mixing, the mixture was heated in an oven at $1050^{\circ} \mathrm{C}$ for $1 \mathrm{~h}$ to dry. The above procedure was repeated to maximize the contact between $A$. niger and activated charcoal.

2.2. Water Sample Preparation. Drinking water samples were filtered and subjected to ultraviolet (UV) digestion for $2 \mathrm{~h}$ before preconcentration. Then the $\mathrm{pH}$ of samples was adjusted with a buffer to 6 and the samples were stored in a cool place.

2.3. General Preconcentration Procedure. The dried biomass was grinded, sieved (with mesh 15), and washed twice by proper amounts of solution with the optimized $\mathrm{pH}$ of
TABLE 1: Measurement condition for determination of arsenic using AA-6650 Shimadzu atomic absorption spectrophotometer.

\begin{tabular}{lc}
\hline Parameter & Setting \\
\hline Wavelength & $193.7 \mathrm{~nm}$ \\
Band pass & $0.5 \mathrm{~nm}$ \\
Signal measurement & AA-BG (peak height) \\
Type of tube & Pyrolytic coated \\
Type of inert gas & Helium \\
Type of lamp & Hallow cathode lamp \\
Lamp current & $10 \mathrm{~mA}$ \\
\hline
\end{tabular}

procedure. $400 \mathrm{~mL}$ of sample containing $10 \mathrm{ng} / \mathrm{mg}$ As was taken and As (V) was reduced to As (III) with $1 \mathrm{~mol} \mathrm{~L}^{-1}$ of KI and ascorbic acid [31]. Then the $\mathrm{pH}$ was adjusted to the optimum value found experimentally with hydrochloric acid or ammonia. 2.0 grams of the prepared adsorbent was added, to the sample solution and mixed for $1 \mathrm{hr}$. the mixed solution passed through a vacuum filter. The resulted cake was quantitatively transferred to a tube, $30 \mathrm{~mL}$ of $1 \mathrm{M}$ sulfuric acid was added and the solution was shaken for $2 \mathrm{~min}$ and then filtered again using vacuum filter. The bottom of the filter paper and sample tube was washed with $10 \mathrm{~mL}$ of $1 \mathrm{M}$ sulfuric acid. $10 \mu \mathrm{L}$ of the filtrate and $10 \mu \mathrm{L}$ of modifier were simultaneously injected to the graphite tube for the determination of arsenic by ET AAS. The recovery of analytes was calculated from the ratio of the concentration found by ETAAS to that calculated theoretically.

2.4. Instruments and Apparatus. An AA-6650 atomic absorption spectrophotometer (Shimadzu Co. Ltd., Japan) equipped with a deuterium lamp background correction system, a GFA-EX7 graphite furnace and an ASC-6100 autosampler was employed for the determination of arsenic. Hallow cathode lamps (HCL) were used as the light source. All the measurements were based on integrated absorbance. The wavelengths used were $193.7 \mathrm{~nm}$ (slit $0.5 \mathrm{~nm}$ ) for arsenic. Pyrocoated graphite tubes, with integrated platforms or L'vov platforms (Shimadzu Co. Ltd., Japan), were used for the atomization of arsenic.

2.5. ETAAS Detection. The samples were analyzed by ETAAS under optimum conditions. The adjustment of instrument was performed according to Table 1 . A mixture of $\mathrm{Pd}\left(\mathrm{NO}_{3}\right)_{2}$ and $\mathrm{Mg}\left(\mathrm{NO}_{3}\right)_{2}$ was used as a chemical modifier for As determination. $10 \mu \mathrm{L}$ of sample solution and $10 \mu \mathrm{L}$ of chemical modifier were simultaneously injected into the pyrocoated graphite tube of furnace. Calibration curve has been used for determination of arsenic amount in samples.

2.6. Reagents. Chemicals were of ultrapure grade and ultrapure water $(18.2 \mathrm{M} \Omega \cdot \mathrm{cm})$, obtained from a Milli-Q water purification system (Millipore, Bedford, MA), was used throughout. A stock standard solution $\left(1 \mathrm{~g} \mathrm{~L}^{-1}\right)$ of arsenic was supplied by Merck (Merck, Darmstad, Germany). Granular activated charcoal (mesh 4-12) was purchased from Ghatran Shimi (Tehran, Iran). Working solutions were obtained by 


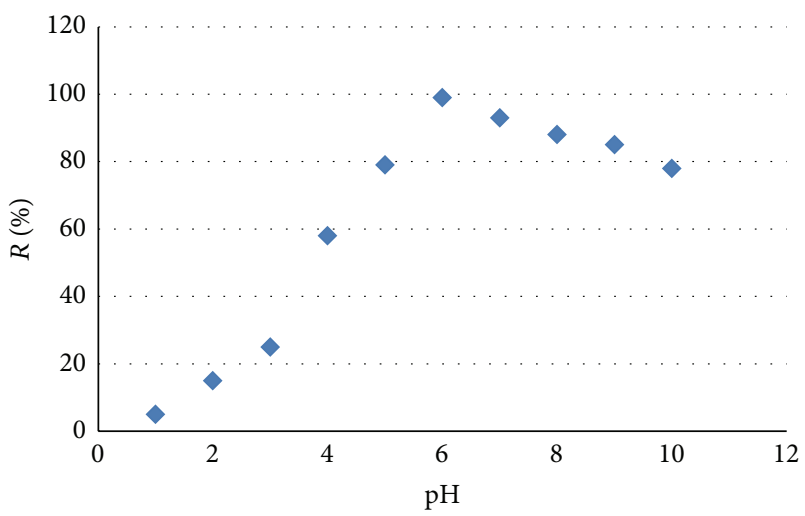

FIGURE 1: Effect of the sample $\mathrm{pH}$ on the preconcentration of arsenic from drinking water sample; experimental condition: $20 \mu \mathrm{g} / \mathrm{L}$ of arsenic, sample flow rate of $5 \mathrm{~mL} / \mathrm{min}$, and the eluent of $\mathrm{HCl} 0.1 \mathrm{M}$.

appropriate dilution of the standard ones. The mixed $\mathrm{Pd}$ and $\mathrm{Mg}\left(\mathrm{NO}_{3}\right)_{2}$ matrix modifier solution was prepared by placing $2.0 \mathrm{~mL} \% \mathrm{Mg}\left(\mathrm{NO}_{3}\right)_{2}$ (Merck, Darmstad, Germany) solution and $2.0 \mathrm{~mL} 1 \%$ Pd solution (Merck) in a $20 \mathrm{~mL}$ volumetric flask and diluting to volume with deionized water. The final concentration of the matrix modifier solution was $0.5 \%$ $\mathrm{Mg}\left(\mathrm{NO}_{3}\right)_{2}$ and $0.1 \% \mathrm{Pd}$. The $\mathrm{HCl}$ (Reagent grade, Merck, Darmstadt, Germany) and) and ammonia 25\% (Merck) were also used for adjusting the $\mathrm{pH}$. KI (Merck) and ascorbic acid (Sigma Aldrich) have been applied for reduction of As (V) to As (III). Argon with $99.999 \%$ purity was used as sheath gas for the atomizer and to purge internally. All glassware was kept in $10 \%$ nitric acid for at least $48 \mathrm{~h}$ and rinsed with ultrapure water before use.

\section{Results and Discussion}

Some preliminary experiments were carried out in order to study the preconcentration of arsenic by the $A$. niger dead biomass loaded on activated charcoal from drinking water samples. Some effective parameters such as $\mathrm{pH}$, elution flow rate, sample volume, type and volume of the eluent, and effect of interfering ions have been investigated.

3.1. Effect of $\mathrm{pH}$. The $\mathrm{pH}$ of the working solution has an important role in adsorption of trace elements on the bioadsorbents in solid phase extraction due to structural groups such as amine and carboxyl on the structure of $A$. niger biomass. Therefore, the effect of $\mathrm{pH}$ on the biosorption of arsenic on the biosorbent was investigated. The effects of $\mathrm{pH}$ were studied in the $\mathrm{pH}$ range of 1-10 by using the dead biomass of $A$. niger. As shown in Figure 1, the retention of arsenic seems to be highly dependent on $\mathrm{pH}$, with maximum retention occurring at $\mathrm{pH} 6$. Therefore, to achieve high efficiency, good sensitivity, and lower detection limit, a $\mathrm{pH}$ of $\sim 6.0$ was selected for subsequent work.

3.2. Type and Volume of the Eluent. The type and concentration of eluent were found to have an important effect on the
TABLE 2: The effect of different amounts of eluents on the recovery of arsenic in the preconcentration procedure.

\begin{tabular}{lccc}
\hline Number & Type of eluent & Conc. of eluent (M) & Recovery \% \\
\hline 1 & $\mathrm{H}_{2} \mathrm{SO}_{4}$ & 0.1 & 92.7 \\
2 & $\mathrm{HCl}$ & 0.1 & 93.9 \\
3 & $\mathrm{H}_{2} \mathrm{SO}_{4}$ & 0.5 & 94.0 \\
4 & $\mathrm{HCl}$ & 0.5 & 96.1 \\
5 & $\mathrm{H}_{2} \mathrm{SO}_{4}$ & 1 & 97.8 \\
6 & $\mathrm{HCl}$ & 1 & 99.1 \\
\hline
\end{tabular}

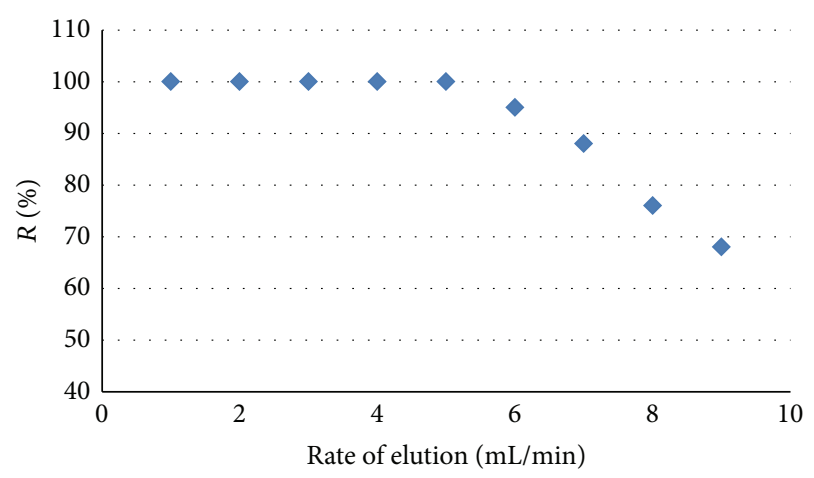

FIGURE 2: Effect of elution rate of column on the preconcentration of arsenic from drinking water sample; $\mathrm{pH}=6,20 \mu \mathrm{g} / \mathrm{L}$ of arsenic, and eluent of $\mathrm{HCl} 0.1 \mathrm{M}$.

desorption process of the retained arsenic from the bioadsorbent. As can be seen from Figure 1, the adsorption of arsenic was negligible at the higher $\mathrm{pH}$; therefore the acidic eluents are suitable for desorption of adsorbed arsenic. Hydrochloric acid and sulfuric acid in different concentrations were used for elution of adsorbed arsenic. The effects of eluent volumes and concentration on the recoveries of the arsenic were also investigated. Table 2 shows the comparison between different acidic solutions for recovery of arsenic. As can be seen from Table 2 diluted $\mathrm{HCl}$ shows good efficiency for recovery of arsenic. Quantitative recoveries of arsenic were obtained with $1 \mathrm{~mol} / \mathrm{lit} \mathrm{HCl}$ as compared to other eluents. Therefore, the $1 \mathrm{~mol} /$ lit $\mathrm{HCl}$ were used in the following experiments to obtain a high sensitivity.

3.3. Effect of Sample Flow Rate. The effect of sample flow rate on the recovery of arsenic was studied in different sample flow rates of $1-9 \mathrm{~mL} / \mathrm{min}$. under optimum condition, no significant reduction in recovery was found for sample flow rate up to $5 \mathrm{~mL} / \mathrm{min}$. Therefore, flow rate of $5 \mathrm{~mL} / \mathrm{min}$ as an appropriate value was the used to continue further experiments. Figure 2 shows the results obtained from this experiment.

3.4. Sample Volume. The effect of the sample solution volume on the arsenic sorption was studied by passing $100-800 \mathrm{~mL}$ volumes. The obtained results have been shown in Figure 3 . According to these results, the adsorption of the arsenic was not affected by sample volume below $400 \mathrm{~mL}$. Above this volume of sample solution, the percent sorption decreased for 


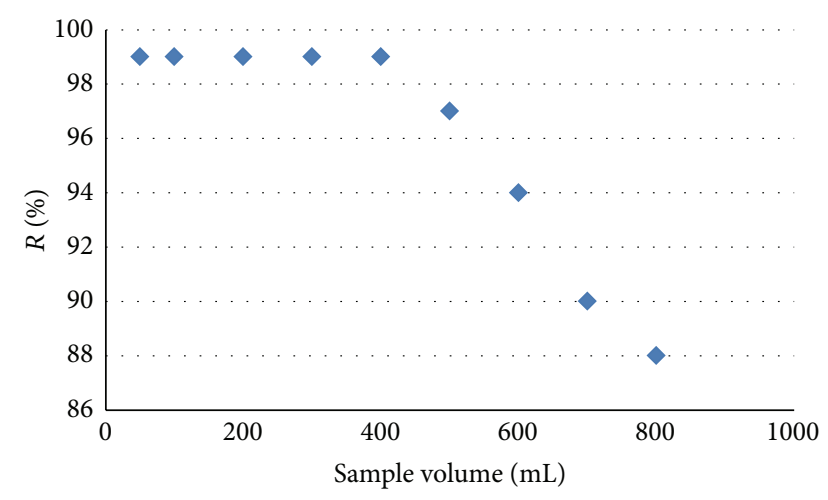

Figure 3: Effect of sample injection volume on the recovery of arsenic; condition: elution flow rate: $5 \mathrm{~mL} / \mathrm{min}$ and $\mathrm{pH}=6$.

the analytes. The recoveries of analytes decrease probably due to the excess analytes loaded over the biomass capacity with increasing sample volume above $400 \mathrm{~mL}$. In the present study $400 \mathrm{~mL}$ of sample solution was adopted for the preconcentration of the investigated ions, the adsorbed metals can be eluted with $20 \mathrm{~mL}$ of $1 \mathrm{~mol} \mathrm{~L}^{-1} \mathrm{HCl}$, and a preconcentration factor of 10 is achieved.

3.5. Effect of Biosorption Time. The influence of biosorption time on recovery of arsenic from drinking water samples has also been studied. According to obtained results (Figure 3) the time longer than $60 \mathrm{~min}$ has no significant effect on the recovery of arsenic from sample solution. Thus the $60 \mathrm{~min}$ was selected as biosorption time for further studies.

3.6. Effect of Interfering Ions. The effects of potential interferences on the recovery of arsenic in water samples were tested using the optimized preconcentration system. In these experiments, $400 \mathrm{~mL}$ of solutions containing $5 \mu \mathrm{g} \mathrm{L}^{-1}$ of arsenic and various amounts of interfering ions were preconcentrated according to the recommended procedure. An ion was considered to interfere when its presence produced a variation in the extraction recovery of sample more than $\pm 5 \%$. The results showed that in excess of 10000 -fold $\mathrm{Li}^{+}$, $\mathrm{K}^{+}, \mathrm{Na}^{+}, \mathrm{Mg}^{+2}, \mathrm{Ca}^{2+}$, and $\mathrm{Ba}^{2+}, 100$-fold $\mathrm{Zn}^{2+}, \mathrm{Fe}^{2+}, \mathrm{Fe}^{3+}$, and $\mathrm{Ni}^{2+}, 500$-fold $\mathrm{Hg}^{+}, \mathrm{Cd}^{2+}, \mathrm{Cu}^{2+}, \mathrm{Mn}^{2+}, \mathrm{Pb}^{2+}, \mathrm{Al}^{3+}$, and $\mathrm{Bi}^{++}$, and 1000 -fold of $\mathrm{PO}_{4}{ }^{3-}, \mathrm{SO}_{4}{ }^{2-}, \mathrm{NO}_{3}{ }^{-}$, and $\mathrm{Cl}^{-}$ions had no significant interferences in the preconcentration and determination of arsenic. The results have been shown in Table 3. This is particularly useful for the analysis of As in natural water samples, for example, seawater, which contains large amounts of alkali and alkaline earth metal ions.

\section{Performance of the System}

The accuracy of the method has been validated using recovery percents of spiked solutions; as can be seen in Table 4, the recovery percents in the range of 99-102 have been achieved after spiking the standard solutions to the sample.
TABLE 3: Effect of diverse ions on the preconcentration of As $(5 \mu \mathrm{g} / \mathrm{L} \mathrm{As})$.

\begin{tabular}{lc}
\hline Ion & $\begin{array}{c}\text { Tolerance limit } \\
\left(C_{\text {ion }} / C_{\mathrm{As}}\right)\end{array}$ \\
\hline $\mathrm{Li}^{+}, \mathrm{K}^{+}, \mathrm{Na}^{+}, \mathrm{Mg}^{2+}, \mathrm{Ca}^{2+}, \mathrm{Ba}^{2+}$ & 10000 \\
$\mathrm{NO}_{3}{ }^{-}, \mathrm{SO}_{4}{ }^{2-}, \mathrm{NO}_{3}{ }^{-}, \mathrm{Cl}^{-}$ & 1000 \\
$\mathrm{Hg}^{+}, \mathrm{Cd}^{2+}, \mathrm{Cu}^{2+}, \mathrm{Mn}^{2+}, \mathrm{Pb}^{2+}, \mathrm{Al}^{3+}, \mathrm{Bi}^{2+}$ & 500 \\
$\mathrm{Zn}^{2+}, \mathrm{Fe}^{2+}, \mathrm{Fe}^{3+}, \mathrm{Ni}^{2+}$, & 100 \\
\hline
\end{tabular}

TABLE 4: Determination of total arsenic in drinking water sample (Taghe Bostan, Kermanshah, Iran) before and after spiking the standard solution of As (III).

\begin{tabular}{lccc}
\hline Number & $\begin{array}{c}\text { Added std } \\
(\mu \mathrm{g} / \mathrm{L})\end{array}$ & Found & Recovery \% \\
\hline 1 & 0 & N.D & - \\
2 & 10 & $10.2 \pm 0.2$ & 102 \\
3 & 20 & $19.8 \pm 0.5$ & 99 \\
4 & 50 & $50.8 \pm 0.4$ & 101.6 \\
\hline
\end{tabular}

The reproducibility of the preconcentration method was evaluated using method for $400 \mathrm{~mL}$ of standard solution of arsenic $(5 \mathrm{ng} / \mathrm{mL})$ and repeating this procedure five times. The relative standard deviation (R.S.D.) was $3.2 \%$, calculated from the peak areas obtained. The calibration graph using the preconcentration system for arsenic was linear with a correlation coefficient of 0.999 . With the proposed system, an enhancement factor of 10 with respect to conventional ETAAS without preconcentration was obtained. The limit of detection (LOD) was calculated as the amount of analyte necessary to yield a signal equal to three times $(3 \sigma)$ of the standard deviation of the blank signals. Using sample volume of $400 \mathrm{~mL}$ a LOD of $1 \mathrm{ng} \mathrm{L}^{-1}$ was obtained for the determination of As. The equation for the linear range of the calibration graph was as follows: Abs $=0.0033$ [As] +0.0003 , $r^{2}=0.999$ (1), where the calibration graph ranged between 5 and $100 \mathrm{ng} \mathrm{mL} L^{-1}$.

\section{Conclusions}

The results showed that the proposed preconcentration procedure provides a fast, simple, and economical method for the enrichment of arsenic from natural water samples. Also, the proposed method was free of interference compared to conventional procedures to determine As. The method can be successfully applied to the separation and determination of As in water samples.

\section{Conflict of Interests}

Authors certify that no actual or potential conflict of interests in relation to this paper exists. 


\section{References}

[1] Y. C. Wang, Food Safety, Hua Hsiang Yuan, Taipei, Taiwan, 1989, (Chinese).

[2] E. Berman, Toxic Metals and Their Analysis, chapter 4, Heyden and Son, London, UK, 1980.

[3] G. M. P. Morrison, G. E. Batley, and T. M. Florence, "Metal speciation and toxicity," Chem Br, vol. 25, no. 8, pp. 791-796, 1989.

[4] W. R. Cullen and K. J. Reimer, "Arsenic speciation in the environment," Chemical Reviews, vol. 89, no. 4, pp. 713-764, 1989.

[5] WHO, Arsenic Compounds Environmental Health Criteria 224, World Health Organisation, Geneva, Switzerland, 2nd edition, 1996.

[6] C. M. Elson, E. M. Bem, and R. G. Ackman, "Determination of heavy metals in a menhaden oil after refining and hydrogenation using several analytical methods," Journal of the American Oil Chemists' Society, vol. 58, no. 12, pp. 1024-1026, 1981.

[7] Pharmaceutical Society of Japan, Standard Methods of Analysis for Hygienic Chemists-with Commentary, Yah Long Publishing, Taipei, Taiwan, 1996, (Chinese).

[8] J. Aggett and A. C. Aspell, "The determination of arsenic(III) and total arsenic by atomic-absorption spectroscopy," Analyst, vol. 101, no. 1202, pp. 341-347, 1976.

[9] D. Slemer, P. Koteel, and V. Jarlwala, "Optimization of arsine generation in atomic absorption arsenic determinations ," Analytical Chemistry, vol. 48, no. 6, pp. 836-840, 1976.

[10] T. Taniguchi, H. Tao, M. Tominaga, and A. Miyazaki, "Sensitive determination of three arsenic species in water by ion exclusion chromatography-hydride generation-inductively coupled plasma mass spectrometry," Journal of Analytical Atomic Spectrometry, vol. 14, no. 4, pp. 651-655, 1999.

[11] M. L. Magnuson, J. T. Creed, and C. A. Brockhoff, "Speciation of arsenic compounds in drinking water by capillary electrophoresis with hydrodynamically modified electroosmotic flow detected through hydride generation inductively coupled plasma mass spectrometry with a membrane gas-liquid separator," Journal of Analytical Atomic Spectrometry, vol. 12, no. 7, pp. 689-695, 1997.

[12] S.-S. Chen, B.-Y. Lee, C.-C. Cheng, and S.-S. Chou, "Determination of arsenic in edible fats and oils by focused microwave digestion and atomic fluorescence spectrometer," Journal of Food and Drug Analysis, vol. 9, no. 2, pp. 121-125, 2001.

[13] J. Michon, V. Deluchat, R. Al Shukry, C. Dagot, and J.-C. Bollinger, "Optimization of a GFAAS method for determination of total inorganic arsenic in drinking water," Talanta, vol. 71, no. 1, pp. 479-485, 2007.

[14] G. Dugo, L. La Pera, V. Lo Turco, and G. Di Bella, "Speciation of inorganic arsenic in alimentary and environmental aqueous samples by using derivative anodic stripping chronopotentiometry (dASCP)," Chemosphere, vol. 61, no. 8, pp. 1093-1101, 2005.

[15] K. Zih-Perényi, P. Jankovics, É. Sugár, and A. Lásztity, "Solid phase chelating extraction and separation of inorganic antimony species in pharmaceutical and water samples for graphite furnace atomic absorption spectrometry," Spectrochimica Acta $B$, vol. 63, no. 3, pp. 445-449, 2008.

[16] C. L. T. Correia, R. A. Gonçalves, M. S. Azevedo, M. A. Vieira, and R. C. Campos, "Determination of total arsenic in seawater by hydride generation atomic fluorescence spectrometry," Microchemical Journal, vol. 96, no. 1, pp. 157-160, 2010.
[17] Y. C. Sun and J. Y. Yang, "Simultaneous determination of arsenic(III,V), selenium(IV,VI), and antimony(III,V) in natural water by coprecipitation and neutron activation analysis," Analytica Chimica Acta, vol. 395, no. 3, pp. 293-300, 1999.

[18] L. Zhang, Y. Morita, A. Sakuragawa, and A. Isozaki, "Inorganic speciation of $\mathrm{As}(\mathrm{III}, \mathrm{V}), \mathrm{Se}(\mathrm{IV}, \mathrm{VI})$ and $\mathrm{Sb}(\mathrm{III}, \mathrm{V})$ in natural water with GF-AAS using solid phase extraction technology," Talanta, vol. 72, no. 2, pp. 723-729, 2007.

[19] S. Baytak and A. R. Türker, "Determination of chromium, cadmium and manganese in water and fish samples after preconcentration using Penicillium digitatum immobilized on pumice stone," Clean-Soil, Air, Water, vol. 37, no. 4-5, p. 314, 2009.

[20] R. Apiratikul and P. Pavasant, "Batch and column studies of biosorption of heavy metals by Caulerpa lentillifera," Bioresource Technology, vol. 99, no. 8, pp. 2766-2777, 2008.

[21] D. Mendil, M. Tuzen, C. Usta, and M. Soylak, "Bacillus thuringiensis var. Israelensis immobilized on Chromosorb 101: a new solid phase extractant for preconcentration of heavy metal ions in environmental samples," Journal of Hazardous Materials, vol. 150, no. 2, pp. 357-363, 2008.

[22] S. Baytak and A. R. Türker, "Determination of Iron(III), cobalt(II) and chromium(III) in various water samples by flame atomic absorption spectrometry after preconcentration by means of Saccharomyces carlsbergensis immobilized on amberlite XAD-4," Microchimica Acta, vol. 149, no. 1-2, pp. 109116, 2005.

[23] T. Ohnuki, T. Ozaki, T. Yoshida et al., "Mechanisms of uranium mineralization by the yeast Saccharomyces cerevisiae," Geochimica et Cosmochimica Acta, vol. 69, no. 22, pp. 5307-5316, 2005.

[24] S. Baytak and A. R. Türker, "The use of Agrobacterium tumefacients immobilized on Amberlite XAD-4 as a new biosorbent for the column preconcentration of iron(III), cobalt(II), manganese(II) and chromium(III)," Talanta, vol. 65, no. 4, pp. 938945, 2005.

[25] M. Rajfur, A. Kłos, and M. Wacławek, “Sorption properties of algae Spirogyra sp. and their use for determination of heavy metal ions concentrations in surface water," Bioelectrochemistry, vol. 80, no. 1, pp. 81-86, 2010.

[26] H. Bag, A. R. Turker, A. Tunceli, and M. Lale, "Determination of $\mathrm{Fe}$ (II) and $\mathrm{Fe}$ (III) in water by flame atomic absorption spectrophotometry after their separation with Aspergillus niger immobilized on sepiolite," Analytical Sciences, vol. 17, no. 7, pp. 901-904, 2001.

[27] S. Baytak, A. Koçyiǧit, and A. R. Türker, "Determination of lead, iron and nickel in water and vegetable samples after preconcentration with Aspergillus niger loaded on silica gel," Clean-Soil, Air, Water, vol. 35, pp. 607-611, 2007.

[28] S. Baytak, A. R. Turker, and B. S. Evrimli, "Application of silica gel 60 loaded with Aspergillus niger as a solid phase extractor for the separation/preconcentration of chromium(III), copper(II), zinc(II), and cadmium(II)," Journal of Separation Science, vol. 28, no. 18, pp. 2482-2488, 2005.

[29] P. Littera, M. Urík, J. Marek, M. Katarína, K. Gardoová, and M. Molnárová, "Removal of arsenic from aqueous environments by native and chemically modified biomass of Aspergillus niger and Neosartorya fischeri," Environmental Technology, vol. 32, no. 11, pp. 1215-1222, 2011. 
[30] A. Pourhossein, M. Madani, M. Shahlaei, K. Fakhri, P. Alimohamadi, and M. Amiri, "Ultrasound assisted pseudo-digestion for determination of iron and manganese in citric acid fermentation mediums by electrothermal atomic absorption spectroscopy," Central European Journal of Chemistry, vol. 7, no. 3, pp. 382-387, 2009.

[31] J. Kowalska, E. Stryjewska, P. Szymański, and J. Golimowski, "Voltammetric determination of arsenic in plant material," Electroanalysis, vol. 11, no. 17, pp. 1301-1304, 1999. 

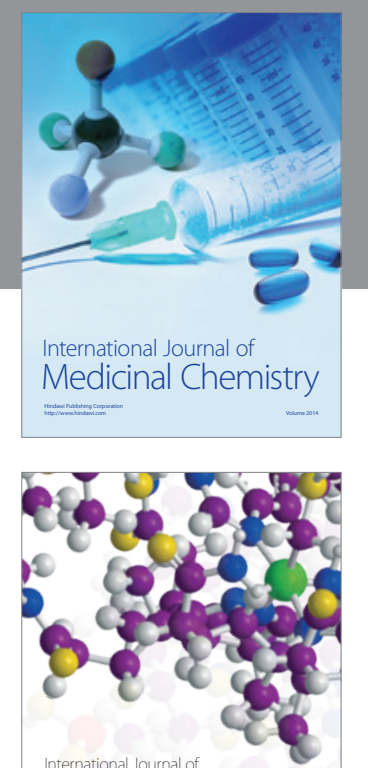

\section{Carbohydrate} Chemistry

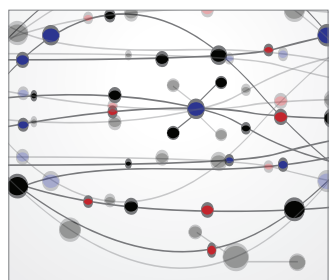

The Scientific World Journal
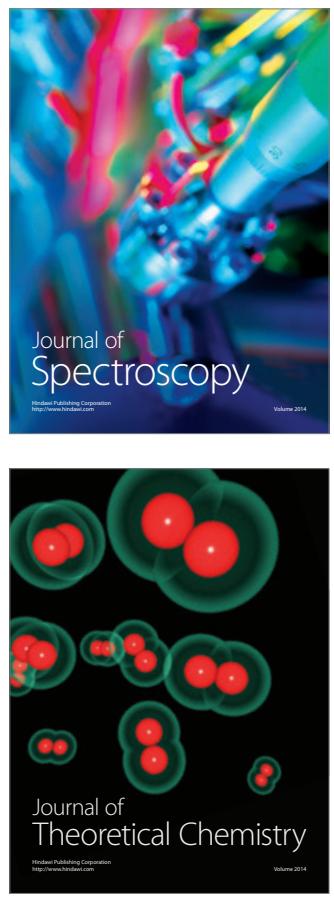
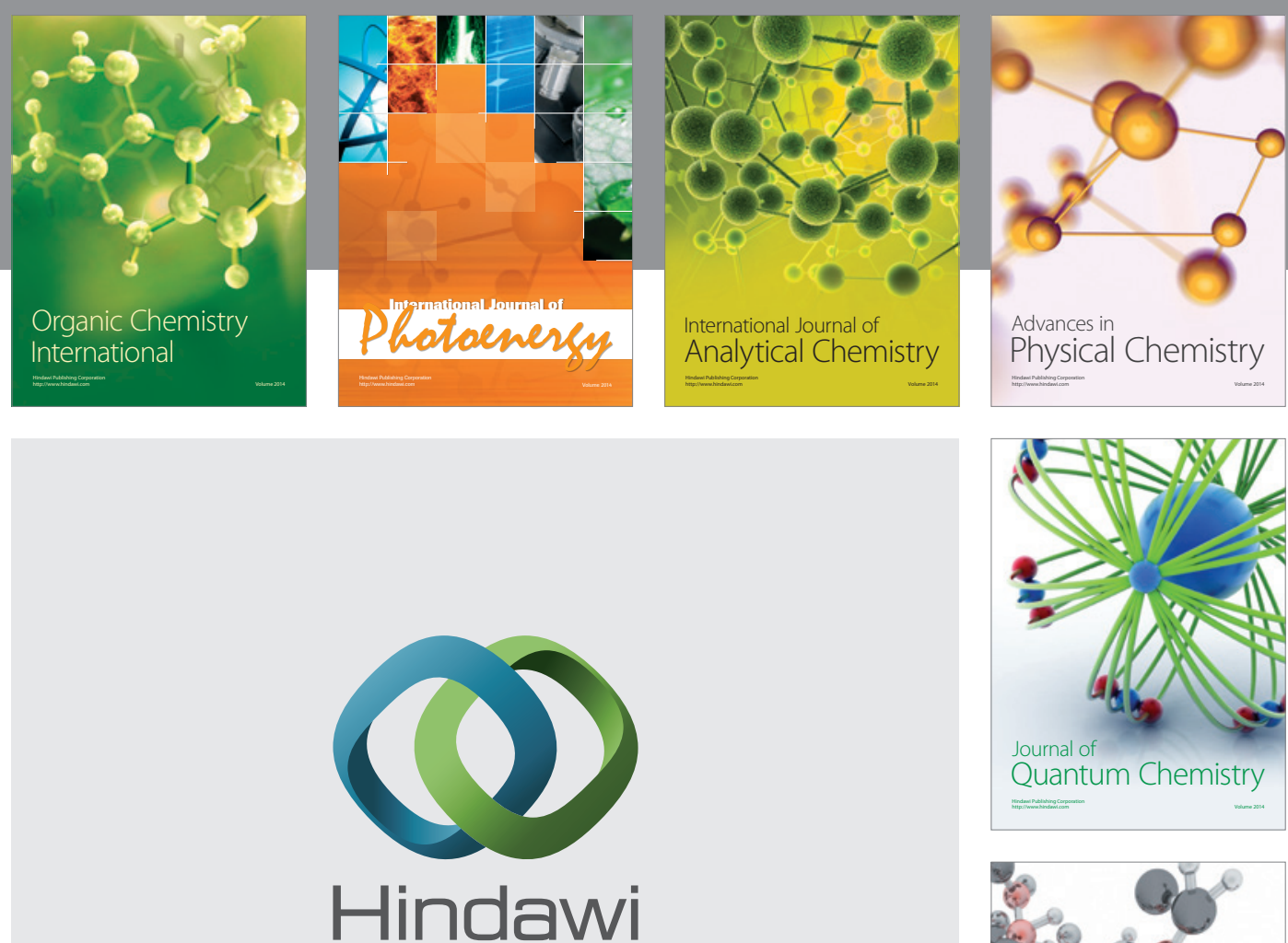

Submit your manuscripts at

http://www.hindawi.com

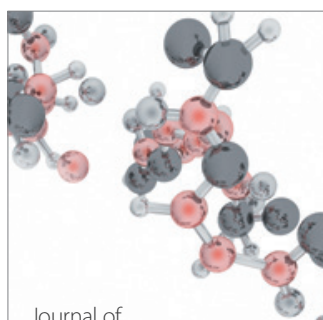

Analytical Methods

in Chemistry

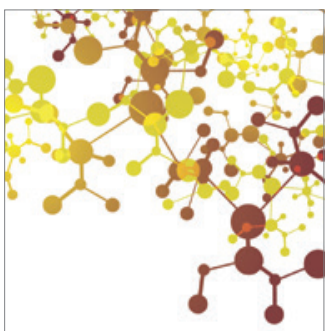

Journal of

Applied Chemistry

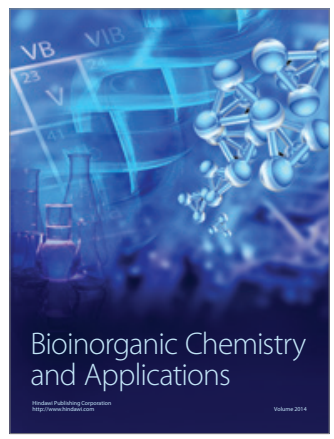

Inorganic Chemistry
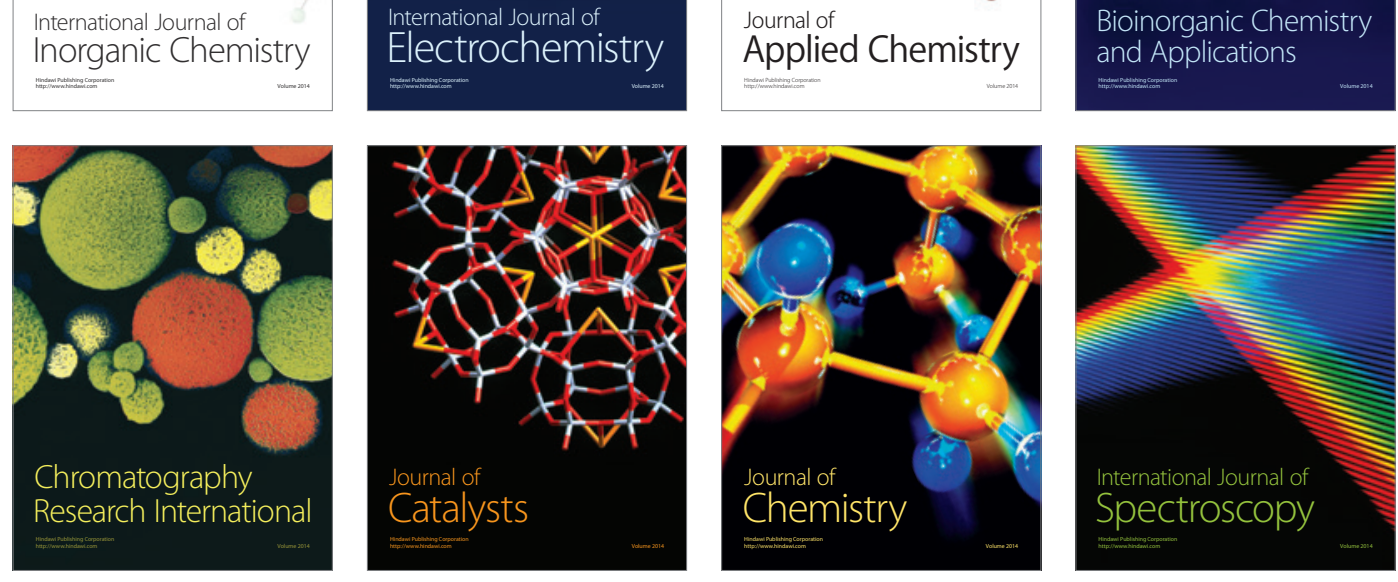